\title{
A NEW LOOK AT THE UNSEAWORTHINESS DOCTRINE: THE ROPER CASE
}

One of the most rapidly changing areas of maritime law during the past twenty years has been that involving the rights of seamen, longshoremen, and other harbor workers to recover damages for personal injuries ensuing from maritime activities. This body of law has developed mainly as a result of Supreme Court litigation. As often happens when such decisions interact with numerous, ambiguously drafted statutes, 1 considerable uncertainty is generated as to the present state of the law.2

The purpose of this comment is to examine in the light of the Supreme Court's most recent pronouncement ${ }^{3}$ the issue of the right of longshoremen and other habor workers to recover under the unseaworthiness doctrine. Under this principle, a shipowner has a duty to provide a "seaworthy" vessel, and as a consequence will be held liable to anyone coming within the scope

${ }^{1}$ See, e.g., the discussion of the areas of maritime employment excluded from the operation of the Longshoremen's and Harbor Workers' Compensation Act of 1927, 44 Stat. 1424 (1927), 33 U.S.C. $\$ \$ 901-50$ (1958), in GILMORE \& BLACK, ADMIRALTY \$ 6-46 (1957) [hereinafter cited as GILMORE \& BLACK].

2 See, e.g., Reed v. S.S. Yaka, 183 F. Supp. 69, 72 (E. D. Pa. 1960). Cf. The Tungus v. Skovgaard, 358 U.S. 588, 601-02 (1959) (separate opinion); Mesle v. Kea S.S. Corp., 260 F.2d 747, 750 (3d Cir. 1958). See generally 1 EDELMAN, MARITIME INJURY AND DeATH 1-6 (1960) [hereinafter cited as Edelman]; Gilmore \& BLACK §6-1; NorRIs, Maritime PerSONAL INJURIES § 1 (1959); Ambler, Seamen are "Wards of the Admiralty" But Longshoremen Are Now More Privileged, 29 WASH. L. REv. 243, 258, 262 (1954); Baer, At Sea with the United States Supreme Court, 38 N.C.L. REv. 307, 307-08 (1960); Gardner, Remedies for Personal Injuries to Seamen, Railroadmen, and Longshoremen, 71 HARv. L. REV. 438 (1958); Tetreault, Seamen, Seaworthiness, and the Rights of Harbor Workers, 39 CORNELL L. Q. 381, 424 (1954); Comment, The Tangled Seine: A Survey of Maritime Personal Injury Remedies, 57 Yale L. J. 243, 271-74 (1947).

While most of the maritime personal injury law has been the result of judicial legislation, see McAllister v. Magnolia Petroleum Co., 357 U.S. 221, 228 (1958) (concurring opinion); Reed v. S.S. Yaka, supra at 72, there have been numerous requests for congressional clarification of the confusion, see generally Ambler, supra at 262; Gardner, supra at 464-65; Comment, 57 YALE L. J. at 271-72, or at least for legislative approval of the liberal personal injury remedies now existing, see Berryhill v. Pacific Far East Line, Inc., 238 F.2d 385, 388 (9th Cir. 1956), cert. denied, 354 U.S. 93 (1957); cf. Senko v. LaGrosse Dredging Corp., 352 U.S. 370, 378-79 (1957) (dissenting opinion). Indeed, the situation today is in such a tumultuous state that it has been said that "the perils of the sea, which mariners suffer and shipowners insure against, have met their match in the perils of judicial review." GiLmore \& BLACK \& 6-1 at 248.

3 Roper v. United States, 368 U.S. 20 (1961). For more general discussions of these rights, see generally Ambler, supra note 2; Baer, supra note 2; Benbow, Seaworthiness and Seamen, 9 MiamI L.Q. 418 (1955); Gardner, supra note 2; Tetreault, Supra note 2; Comment, The Doctrine of Unseaworthiness in the Law of Maritime Personal Injuries, 21 LA. L. REV. 755 (1961). 
of the doctrine for any injury proximately caused by its breach. ${ }^{4}$ Although it is a "species of absolute liability," the concept of unseaworthiness does not impose upon the owner the duty of furnishing an accident free vessel.5 The owner is not required to become an insurer, as under workmen's compensation acts, but rather is required to provide a vessel and appurtenances which are "reasonably fit for their intended use."6 Since these "uses" are subject to countless permutations, it is clear that unseaworthiness is a relative doctrine. - The consequence of this relativity is that the duty will vary with the type of vessel involved and the type of service for which the vessel was designed or for which it is being used.7

${ }^{4}$ Even though the remedy has been said to be "essentially a species of liability without fault analogous to other well known instances in our law," Seas Shipping Co. v. Sieracki, 328 U.S. 85, 94 (1946), it should be pointed out that this is true only in that the duty is nondelegable, see, e.g., Alaska S.S. Co. v. Petterson, 347 U.S. 396 (1954); but see, e.g., West v. United States, 361 U.S. 118, 123-24 (1959), and that the duty is not abrogated by the exercise of due care, see, e.g., Seas Shipping Co. v. Sieracki, supra. Before recovery can be had for an unseaworthiness claim, it is necessary to prove that (1) an unseaworthy condition existed; (2) the injury was proximately caused by the condition; and (3) the duty was owed to the injured party. See, e.g., Blier v. United States Lines Co., 286 F.2d 920 (2d Cir. 1961); Arena v. Luckenbach S.S. Co., 279 F.2d 186 (1st Cir. 1960); Green v. Skibs A/S Mandeville, 186 F. Supp. 459 (E.D.S.C. 1960); Cimino v. United States, 1960 Am. Mar. Cas. 2120 (S.D.N.Y. 1960); cf. Holley v. The Manfred Stansfield, 269 F.2d 317 (4th Cir. 1959).

The determination as to the existence of an unseaworthy condition is one of fact; $c f$. Butler v. Whiteman, 356 U.S. 271 (1958); but see Puddu v. Royal Netherlands S.S. Co., $1962 \mathrm{Am}$. Mar. Cas. 419 (2d Cir. 1962) (dissenting opinion) and as a consequence the findings will not be upset unless "clearly erroneous." McAllister v. United States, 348 U.S. 19, 20-21 (1954).

5 See, e.g., Phipps v. N.V. Nederlandsche Amerikaanische Stoomvart, Maats., 259 F.2d 143, 145 (9th Cir. 1958); Manhat v. United States, 220 F.2d 143 (2d Cir. 1954), cert. denied, 349 U.S. 966 (1955). See also note 4 supra and accompanying text.

It is possible that the reluctance of the courts to accept a theory of tort recovery that is not couched in terms of the familiar "reasonable man" has been the cause of some of the trouble that they have had shaping the remedy. See Ezekiel v. Volusia S.S. Co., 297 F.2d 215, 218 (2d Cir. 1961) (dissenting opinion); Grillea v. United States, 232 F.2d 919, 923 (2d Cir. 1956). What the courts have to accept is that the doctrine "does not mean . . that the shipowner] must make only reasonable efforts to furnish seaworthy appliances. He has an absolute duty to furnish a reasonably fit ship." Ezekiel v. Volusia S.S. Co., supra at 218. See also note 4 supra. This difficulty can be readily appreciated when it is understood that much of the general maritime law has no precise counterpart in the law of land based activities.

It should be pointed out, however, that even terms unique to maritime law have different meanings in different contexts. For example, the doctrine of seaworthiness as applied in personal injury situations is not the same as the doctrine applied to damaged cargo shipments under the Harter Act, 27 Stat. 445 (1893), 46 U.S.C. $\$ \S 190-95$ (1958). In the latter situation "the ship is . .. freed from liability by mere due diligence to render her seaworthy . . . [because the] loss[es] result from faults in navigation...." The H. A. Scandrett, 87 F.2d 708 (2d Cir. 1937).

6 Mitchell v. Trawler Racer, Inc., 362 U.S. 539, 550 (1960).

7 See, e.g., Mitchell v. Trawler Racer, Inc., 362 U.S. 539, 550 (1960); Lester v. United States, 234 F.2d 625, 628 (2d Cir. 1956); McAllister Lighterage Line, Inc., v. Insurance Co. of North America, 244 F.2d 867, 870 (2d Cir. 1957); Henry Gillens' Sons Lighterage v. Fernald, 294 Fed. 520, 527 (2d Cir. 1923); McDaniel v. The M/B Lisholt, 180 F. Supp. 24, 26 
Although the major changes in this area have occurred within the past two decades, the history of the 'unseaworthiness remedy prior to the early 1940's should be surveyed in order to show not only how the doctrine has developed from dictum, but also to indicate the rationale supporting its application to longshoremen and harbor workers. The warranty of seaworthiness was first applied to seamen by implication in early cases of wage forfeiture for abandonment of the ship before the completion of the voyage. A typical case was Dixon v. The Cyrus. ${ }^{8}$ The crew had abandonned the vessel before the cargo was discharged because the owner had failed to provide meals after the ship had reached port. In allowing the crew's claim for wages, the court observed that, while the shipping articles contained no express warranty of seaworthiness, there was an implicit obligation on the part of the owner to provide a seaworthy vessel. The court held that this obligation required not only that the ship have the "customary requisites for navigation" but also that it be stocked with adequate provisions. 9

Probably the landmark decision in the entire field of maritime personal injuries is that of The Osceola. 10 In the opinion, Mr. Justice Brown expounded four propositions that were allegedly "settled" in the law of admiralty. Of the four, only the second is of major interest to this comment. This proposition held "that the vessel and her owner, are, both by English and American law, liable to an indemnity for injuries received by seamen in consequence of the unseaworthiness of the ship, or a failure to supply and keep in order the proper appliances appurtenant to the ship."11 While this proposition, as well as the other three, is often cited as authority for the absolute nature of the unseaworthiness doctrine, 12 such a conclusion is questionable if examined in the context of the issues involved in the litigation. In The Osceola a crew

(S.D.N.Y. 1959); Sanderson v. Sause Bros. Ocean Towing Co., 114 F. Supp. 849, 852 (D. Ore. 1953); Gibson v. Small [1853] 94 Rev. R. 138. See also 1 EdELMAN 153-56; NorRIS, Maritime Personal InJuRies $\$ \S 27,31$ (1959); 2 Norris, Seamen $\S 609$ (1952) and cases cited therein.

Unseaworthiness claims, whether brought by seamen or harbor workers, appear to fall into "two [general] categories. . . . One is where the shipowners having knowledge-actual or constructive - that certain activity will occur, is imposed with an absolute duty of supplying equipment for permitting the conduct and accomplishment in reasonable safety of that activity; liability is imposed for failure to comply with this duty, termed one of making the vessel seaworthy. The other category is where the equipment actually supplied by the owner for doing the ship's work proves incapable of performing its functions in the manner for which it was designed." Mesle v. Kea S.S. Corp., 260 F.2d 747, 750-51 (3d Cir. 1958). (Footnotes omitted.) For a thorough annotation of the authorities, see $260 \mathrm{~F} .2 \mathrm{~d}$ at $751-52$ nn. 6-7.

87 Fed. Cas. 755 (No. 3930) (D. Pa. 1789). See also The Moslem, 17 Fed. Cas. 894 (No. 9875) (S.D.N.Y. 1846).
9 Id. at 757.
10189 U.S. 158 (1903).
11 Id. at 175.

12 See, e.g., Pope \& Talbot, Inc. v. Hawn, 346 U.S. 406, 414 (1953) (concurring opinion); Seas Shipping Co. v. Sieracki, 328 U.S. 85, 90 (1946); Mahnich v. Southern S.S. Co., 321 U.S. 96, 99, 104 (1944). 
member had libeled the ship in rem for injuries sustained in carrying out an order given by the ship's master. It would seem to be a clear case involving "operating negligence," and the narrow holding of the decision was that a seaman could not recover for injuries proximately caused by such negligence. Apparently the seaworthiness of the vessel had been conceded, ${ }^{13}$ and hence there was no need for Mr. Justice Brown to give this issue careful consideration. Since the proposition was dictum, it is probable that it was treated without appreciation of its subsequent importance. ${ }^{14}$

A third important case in the development of the remedy was The Max Morris. ${ }^{15}$ This case is notable not for a discussion of unseaworthiness but rather as a recognition that:

the work of longshoremen [is] a maritime service; the right of habor workers to proceed against a vessel for damages arising out of tort; that a tort occurring aboard a vessel in navigable waters, albeit the territorial waters of a state, was cognizable in admiralty; and that in the case of maritime personal injury, contributory negligence did not bar the injured suitor from recovery. 16

Of all the maritime tort cases Southern Pacific Co. v. Jensen ${ }^{17}$ has probably been the most severely criticized. The Court in Jensen held, over a vigorous four member dissent, that a state workman's compensation statute was unconstitutional as applied to a longshoreman injured under circumstances constituting a maritime tort. The Court reasoned that since the activity was maritime the remedy could not be allowed if it was inconsistent with any congressional act because of the federal nature of maritime law. The Court held that the "remedy ... [was] not consistent with the policy of Congress to encourage investments in ships" 18 as exemplified in acts limiting liability of shipowners. The result of Jensen was that the courts became inclined to create new tort remedies for harbor workers because the compensation remedy was not

13189 U.S. at 159. Indeed, the only authority cited for this proposition was Scarff v. Metcalf, 107 N.Y. 211 (1887). The holding in Scarff, however, was that the owners of the ship were liable for the negligence of the ship's master in failing to provide adequate medical care for an ill seaman. The case seems to be more in line with the actual holding of the Osceola, notwithstanding its contrary result, than with the proposition for which it was cited. Certainly this is true if the proposition is examined in the light of contemporary interpretation. Apparently Mr. Justice Brown did not consider Dixon and its antecedents as authority. He did, however, discuss several lower federal court decisions which, while couched in terms of negligence, were possibly decided on an "unseaworthiness" basis.

14 For more thorough discussions of the Osceola decision see generally 1 EDELMAN 1, 9, 18, 63, 93, 150, 171, 674; GrLmore \& BlacK \$§ 6-2-6-3; Norris, MARItime Personai INJURIES § 19 (1959); 2 NoRRIS, SEAMEN \$§ 541, 548, 551, 556, 571, 608, 611, 613, 645 (1952); Robinson, Admiralty, 291, 294-96, 303-06, 310 (1939); Ambler, supra note 2, at 260; Benbow, supra note 3, at 418-22: Tetrault, supra note 2, at 385-403; Note, 6 N.Y.L.F. 491, 493 (1960).

15137 U.S. 1 (1890).

16 Norris, Maritime Personal Injuries § 18 at 41 (1959).

17244 U.S. 205 (1917).

18 Id. at 218. 
available. Illustrative of such circumvention of Jensen was International Stevedoring Co. v. Haverty, 19 where a longshoreman was permitted to sue as a "seaman" under the Jones Act20 for the negligence of a fellow servant. The Court argued that the term seamen, as used in the act, should be broadly interpreted. Since longshoremen were now engaged in "maritime service formerly rendered by the ship's crew," 21 ergo the respondent was within the class Congress had intended to protect in the passage of theact. 22 Congress promptly manifested its contrary intention by enacting the Longshoremen's and Harbor Workers' Compensation Act, 23 which provided the exclusive remedy for such a worker against his employer. ${ }^{24}$

The process of turning The Osceola dictum into law commenced in Mahnich v. Southern S.S. Co.25 and was continued and expanded in Seas Shipping Co. v. Sieracki.26 In Mahnich, the plaintiff seaman was barred from bringing a Jones Act suit for the negligence of the ship's mate because of the statute of limitations. The Court, however, allowed an unseaworthiness recovery, noting inter alia the absoluteness of the doctrine and its applicability to the appurtenants of the ship. The Osceola's proposition in conjunction with the little known decision in Carlisle Packing Co. v. Sandanger 27 was cited as authority. Since the injury was caused by the failure of a piece of defective rope used to support a staging upon which the plaintiff was working, although serviceable rope was available, the case really involved a question of operating negligence. In this respect the Mahnich situation was closer to the controverted point in the Osceola decision than it was to the dictum which was turned into law.28 Relying on the Mahnich interpretation of the unseaworthiness doctrine, Sieracki extended the remedy to a longshoreman injured when a shackle on a cargo boom broke, causing the boom and tackle to fall upon him. The in-

19272 U.S. 50 (1926. The opinion was written by Mr. Justice Holmes, who had written one of the two vigorous dissents in Jensen.

2041 Stat. 1007 (1920), 46 U.S.C. $\$ 688$ (1958). The effect of the Jones Act was to extend the remedy possessed by railroadmen under FELA to "seamen." For an excellent discussion of the Jones Act, see Gilmore \& BLACK $\S 6-20-6-37$. See also NORRIS, MARITIME Personal INJuRIes $\$ \S 13,69-70,126$ (1959).

21272 U.S. at 52.

$22 \mathrm{Mr}$. Justice Holmes cited Atlantic Transp. Co. v. Imbrovek, 234 U.S. 52 (1913), as authority for the proposition that longshoremen were rendering services previously rendered by the crew. Mr. Justice McReynolds had also cited Imbrovek for that proposition in his majority opinion in Jensen. However, since Imbrovek considerable doubt has been cast on the historical accuracy of this premise in the context of loading and unloading the vessel. See generally Tetreault, supra note 2.

2344 Stat. 1424 (1927), 33 U.S.C. $\$ \S 901-50$ (1958).

2444 Stat. 1424 (1927), 33 U.S.C. $\$ 905$ (1958).

25321 U̇.S. 96 (1944).

26328 U.S. 85 (1946).

27259 U.S. 255 (1922).

28 In achieving this result the Court was required expressly to disapprove Plamals v. The Pinar del Rio, 277 U.S. 151 (1928), a case similar on the facts, where it was held that such operating negligence did not constitute an unseaworthy condition. 
jury was the result of a defect in the forging of the shackle that could not 'have been discovered by testing. Even though Congress had disapproved the broad interpretation of "seaman" as used in Haverty in the enactment of the Longshoremen's Act, ${ }^{29}$ the Court placed great stress on the fact that Sieracki was doing the traditional work of seamen and hence incurring their hazards. As a result, it held that longshoremen could take advantage of the seaman's traditional tort remedies. ${ }^{30}$ In effect, Sieracki was the fortuitous combination of dictum which became law, ${ }^{31}$ and somewhat anachronistic reasoning which resulted in giving longshoremen a greater range of tort remedies than those possessed by seamen who are often called "wards of the admiralty." 32 The Sieracki doctrine was extended to other harbor workers in Pope \& Talbot $v$. Hawn, 33 where a carpenter was allowed to recover for injuries sustained while repairing the grain loading equipment of a vessel. The Court reasoned that the mere labels of employment should not deprive such maritime workers of the unseaworthiness remedy. 34

In Roper, however, a longshoreman injured while unloading grain from a vessel owned by the United States was denied recovery on his unseaworthiness claim. The plaintiff had brought an in personam libel against the United States pursuant to the Suits in Admiralty Act. ${ }^{35}$ The ship involved in the litigation, a World War II liberty vessel which had been deactivated and moored in a

29 It is clear that $\S 905$ of the Longshoremen's Act did negate the holding of Haverty that a longshoremen could bring a Jones Act suit against his employer. See, e.g., Swanson v. Marra Bros., Inc., 328 U.S. 1 (1946), decided on the same day as Sieracki.

30328 U.S. at 98-100. That Chief Justice Stone, writer of the Mahnich opinion, did not consider this extension to be an a fortiori consequence of Mahnich is apparent in his dissent. $I d$. at 103 . The difficulty occasioned by a denial of recovery is suggested by the majority's view that Mahnich could easily be emasculated by shipowners who contract out all the ship's work, including the actual running of the vessel.

31 The petitioner in Sieracki might have done a disservice to shipowners by apparently conceding the absoluteness of the doctrine as applied to seamen. See Brief for Petitioner, pp. 5-6, Seas Shipping Co. v. Sieracki, 328 U.S. 85 (1946). If this point had been argued it is possible that the Court would have departed from the position taken in Mahnich.

32 See generally Ambler, supra note 2.

33346 U.S. 406 (1953). In his concurring opinion, Id. at 417, Mr. Justice Frankfurter made the observation that the effect of Sieracki might have been to eliminate the longshoreman's negligence cause of action against the shipowner becuase of the Osceola holding taken in conjunction with the treatment of a longshoreman as a seaman. In Crumady $v$. The Joachim Hendrik Fisser, 358 U.S. 423 (1959), it was held that the acts of the longshoreman himself could make the vessel pro tanto unseaworthy.

34 For more detailed treatment of the unseaworthiness remedy, see generally 1 EDELMAN 1-6, 145-200, 226-37; GILMORE \& BLACK \$§ 6-1-6-5, 6-38-6-44, 6-53-6-57; NoRRIS, Maritime Personal INJURIes $\S \S 1-2,14-48 C$ (1959); 2 Norris, Seamen $§$ 606-22 (1952), 1 BENEDICT, AdMIRALTY § 83 (6th ed. 1940); RoBinson, AdMIRALTy 303-07 (1939); Ambler, supra note 2; Benbow, supra note 3; Gardner, supra note 2; Tetreault, supra note 2; Note, 6 N.Y.L.F. 491 (1960).

3541 Stat. 525 (1920), 46 U.S.C. $\$ 742$ (1958). 
"mothball" fleet at the cessation of hostilities, 36 had been loaded with grain in order to implement the land based storage facilities of the farm surplus program. In 1956 she was again towed from the fleet in order to discharge the grain which had subsequently been sold. The plaintiff was employed by the stevedore ${ }^{37}$ who had contracted with the purchaser to effectuate the unloading process. The elevator was equipped with a land based unloading device known as a "Marine Leg," which when lowered into the hold of a ship would lift the grain to the elevator by means of scoops and conveyor belts. When the grain in the hold reached a certain level, it was necessary to draw the balance to the leg by means of "grain shovels." The plaintiff was injured when a block used in the manipulation of the shovels broke, striking him in the face. ${ }^{38}$ The district court dismissed the action, finding that the ship was not in "navigation" 39 and that hence the United States had not warranted the seaworthiness of the unloading equipment. 40 The Court of Appeals for the Fourth Circuit agreed with the lower court's determination of the navigation question and held further that the warranty would not extend to the land based equipment even if the ship had in fact been in navigation.41 The Supreme Court, three justices dissenting, affirmed on the basis of the navigation finding but did not reach the second question. 42

The determination of the navigation question turns on the "status of the ship." 43 Even the most avid supporters of the Sieracki and Pope \& Talbot rationale admit that some such limitations must be delineated in order to prevent the inclusion of all quasi-maritime activities within the scope of the unseaworthiness doctrine. ${ }^{44} \mathrm{It}$ must also be agreed that since navigation is a

36368 U.S. at 21 . This process consists of stripping the vessel of her supplies, stores, and nautical instruments; removing her cargo gear and tackle; draining her pipes and machinery; and securing her running gear.

37 While the term stevedore and longshoreman are often used interchangeably, they are not synonymous. The stevedore is usually defined as the person supervising the work, while the longshoreman is the workman who actually does the physical aspect of the work.

38368 U.S. at 22.

39 The question of navigation has been said to be one of fact. Butler v. Whiteman, 356 U.S. 271 (1958).

40170 F. Supp. 763 (E.D. Va. 1959). The requirement that the ship be in navigation is not only a prerequisite for the warranty of seaworthiness, but also for the determination of a "seaman" status under the Jones Act. See, e.g., Antus v. Interocean S.S. Co., 108 F.2d 185 (6th Cir. 1939); Hunt v. United States, 17 F. Supp. 578 (S.D.N.Y. 1936), aff'd, 91 F.2d 1014 (2d Cir. 1937). Cf. Butler v. Whiteman, 356 U.S. 271 (1958); South Chicago Co. v. Bassett, 309 U.S. 251 (1940).

41282 F.2d 413 (4th Cir. 1960), 47 VA. L. Rev. 329 (1961).

42368 U.S. 20 (1961).

43 West v. United States, 361 U.S. 118, 122 (1959). Cf. Butler v. Whiteman, 356 U.S. 271 (1958). See also note 4 supra.

44 Certainly Judge Sobeloff, who wrote the vigorous dissent in Roper, acknowledges the need for limits on the doctrine. In Noel v. Isbrandtsen Co., 287 F.2d 783 (4th Cir. 1961), 
question of fact, the court of appeals in Roper, as well as the Supreme Court, was restricted in its scope of review. 45 Nevertheless, no sound reason is apparent for rejecting the view that the ship in Roper was in fact in navigation from the time it was removed from the mothball fleet until the time it was returned to the fleet. ${ }^{46}$ It would not seem unreasonable to say that, in effect, the Harry Lane had become a barge and was therefore subject to the warranty of seaworthiness, ${ }^{47}$ and was involved in a commercial activity 48 because it was used to transfer cargo a distance of approximately twenty miles. A second reason why a result opposite to the one reached in Roper would be logically sound is that even though Mr. Justice Clark talks in terms of a "floating warehouse," 49

the court affirmed a dismissal of a libel by a marine surveyor injured while inspecting a ship about to be returned to a mothball fleet. Judge Sobeloff writing for the court explained that in Roper he had "differed with the majority as to whether that was a dead ship, but here there is no room to doubt the William Bevan's status. She was no longer performing nor was she able or expected to perform any of a vessel's duties. We are unhesitatingly of the opinion that she was completely and permanently withdrawn from service and hence the warranty of seaworthiness was not applicable." Id. at 785. Cf. Berge v. National Bulk Carriers Corp., 251 F.2d 717, 718 (2d Cir. 1958). See also note 4 supra.

45 However, since the determination of this issue was in no way dependent upon the credibility of witnesses or upon the expertise of the court of first instance, this determination could have been reviewed much more fully than findings that are based upon an advantageous position of the trier of fact. Because the reviewing courts in Roper were no less competent to pass on the navigation issue, there was little reason for them to defer to the district court. See Steffen, The Prima Facie Case in Non-Jury Trials, 27 U. CHI. L. REv. 94, 121-24 (1959), where the author argues that appellate courts are better able "to pass on the law and facts of a case" than a trial court and are justified in doing so under the rationale of Rule 52(a) of the Fed. R. Civ. P. See also 4 Davis, Administrative Law $\S \S 30.02-30.04$ (1958); note 4 supra.

46 See Noel v. Isbrandtsen Co., 287 F.2d 783 (4th Cir. 1961). The status of the ship in Noel, prior to being "redeactivated" was similar to the status of the Harry Lane in Roper. Certainly there would have been no question as to the William Bevan being in navigation during the year in which it was in active service. The William Bevan was not a "dead ship" during that year and neither was the Harry Lane during its absence from the mothball fleet. This is a most reasonable position if it is recalled that the warranty is that the ship is reasonably fit for its intended use. See notes 6-7 supra and accompanying text. See also note 44 supra.

The reliance by both the district and circuit courts in Roper, 170 F. Supp. at $765 ; 282$ F.2d at 415 , on the lack of Coast Guard documentation in determining whether or not the ship was in navigation is also questionable. The removal of such documentation and the concomitant cessation of inspection is really a matter of Coast Guard convenience. See The Joshua Leviness, 13 Fed. Cas. 1155 (No. 7549) (E.D.N.Y. 1878); but see Hawn v. American S.S. Co., 107 F.2d 999, 1000 (2d Cir. 1939) (per curiam). See also Hercules Co. v. The Brigadier Gen. Absolem Baird, 214 F.2d 66 (3d Cir. 1954).

${ }^{47}$ See, e.g., Goett v. Union Carbide Corp., 261 U.S. 340 (1960); Summerlin v. Massman Constr. Co., 199 F.2d 715 (4th Cir. 1952). Cf. Ellis v. United States, 206 U.S. 246 (1907); Ex Parte Easton, 95 U.S. 68 (1877); Jeffrey v. Henderson Bros., 193 F.2d 589 (4th Cir. 1951).

48 See, e.g., Gonzales v. United States Shipping Bd. E. F. Corp., 3 F.2d 168, 170 (E.D.N.Y. 1924). See also The Joshua Leviness, 13 Fed. Cas. 1155 (No. 7549) (E.D.N.Y. 1878).

49368 U.S. at 23. 
there is nothing inherent in the concept of a barge that would pro tanto prohibit such a use. The district Court Judge in Roper apparently was cognizant of the interrelationship of commerce, navigation, and the warranty of seaworthiness when he said that "seaworthiness contemplates a vessel which will, in due time, be used for the purpose of navigation. ..." $50 \mathrm{He}$ did qualify this statement, however, by adding "not a ship which was once used for such purpose and is now adopted ... as a warehouse which requires occasional towage ... for service or sale of its cargo." 51 This qualification seems questionable, however, if it is remembered that the entire concept of seaworthiness is relative to the intended use of the vessel.52 There is no logical reason why the intended use must be continuous or even commonplace. Judge Sobeloff relied on this rationale in his dissent, when he argued that the vessel was not, in fact, a "dead" ship.53 The Supreme Court, in a footnote, admitted that "the view that a vessel not in navigation extends no warranty has often been expressed in the more familiar context of to whom does the warranty extend." 54 However, the Court apparently ignored this observation, since the application of the traditional test of Sieracki would seem to bring the ship within the ambit of the warranty. This would be so notwithstanding the possible historical inaccuracies of the premise. 55

From the above discussion, it seems clear that Roper, while concededly involving a question of degree, should have been decided in favor of the plaintiff longshoremen on the navigation issue. Since the granting of relief to the plaintiff in Roper could not be considered an improper application of the Sieracki doctrine, it is submitted that the rejection of this result manifests a judicial dissatisfaction with the doctrine. The implication of the Roper decision is that under no circumstances will the warranty apply to a deactivated vessel until it has been completely refurbished and recommissioned, with the concomitant result that a segment of the workers who seek the protection presented by Sieracki will be deprived of the remedy provided by the seaworthiness doctrine. The magnitude of this holding becomes apparent when it is realized that the "hazards" faced by Sieracki-were no greater than those faced by Roper in the context of the traditional seamen's work.

The holding of Roper may be attributed to an overreliance on West $v$. United States ${ }^{56}$ and that line of cases. In West the plaintiff repairman was

so 170 F. Supp. at 770. s1 lbid.

s2 See notes 6-7 supra and accompanying text. See also, Carumbo v. Cape Cod S.S. Co., 123 1.21 991 (Ist (ir. 1941); Madsen v. United States, 186 F. Supp. 577 (E.D. Pa. 1960).

si 282 F.2. at 418. See generally Note, 47 VA. L. Rev. 329 (1961).

436 (I.S. at 24 n. 3

"Sic nole 22 supros.

63 31 U.S. 118 (1959). II'st was an unusual maritime personal injury decision in that it was hy :al unamumbus ('ourt. Mtany of the recent decisions by the Supreme Court have bern hy ucty clese majoritics. Scec also note 2 supra and accompanying text. For a brief dis- 
injured while a complete reactivation of a mothballed liberty ship was being made. The Court denied recovery under an unseaworthiness claim, holding that the vessel was not in navigation while dry-docked for the extensive repairs and hence that there could be no warranty. This result is justified because the admitted purpose of the work was to make the ship seaworthy. Indeed, an extension of the unseaworthiness doctrine to such a situation ${ }^{57}$ would be unwarranted notwithstanding the relative nature of the doctrine. 58 The decision in West did not really set an outer limit to Pope \& Talbot because, applying the traditional work test, it is doubtful that any seaman ever did any major structural repairs in his vessel other than in an emergency. The West decision would also seem to suggest Supreme Court approval of the uniform policy of the lower federal courts in dealing with injuries occurring during a reactivation or major overhauling of a vessel.59

cussion of the result of these close decisions see Baer, At Sea With the United States Supreme Court, 38 N.C.L. REv. 307, 307-08, 364-54 n. 210 (1960).

Another factor in the Roper decision was a reliance on the circuit court decision in Hawn v. American S.S. Co., 107 F.2d 999 (2d Cir. 1939) (per curiam), a case similar to Roper on its facts. The plaintiff in Hawn, although a seaman by vocation, was injured while working as a longshoreman on a deactivated vessel being used to store soya beans. The question was whether he could sue as a seaman under the Jones Act or was restricted to only the relief afforded by the Longshoremen's Act. In holding that Hawn was not a "member of a crew" the court spoke in terms of the ship's being out of navigation. It must be pointed out, however, that Hawn was a pre-Sieracki decision and hence dubious authority in view of the liberal spirit of the Sieracki doctrine. This fact was noted in the Roper dissent. 282 F.2d at $418 \mathrm{n}$.2. The approving citation of Hawn in Desper v. Starved Rock Ferry Co., 342 U.S. 187, 195 (1952) does not effect this conclusion because it was cited for the crew member proposition rather than for the navigation proposition.

57 Similarly it would be unreasonable to extend the warranty to an individual working on an incomplete but just launched vessel, see Frankel v. Bethlehem-Fairfield Shipyard, Inc., 132 F.2d 634 (4th Cir. 1942), or to a fireman guarding a ship which had just suffered a serious fire, McDaniel v. M/S Lisholt, 180 F. Supp. 24 (S.D.N.Y. 1959), Aff'd, 282 F.2d 816 (2d Cir. 1960).

58 The argument that the owner should at least warrant that the ship is in such a condition that the refurbishing can be safely effected is not persuasive. To accept such a contention would result in a doctrine virtually without limit. It must be remembered that the ship is being repaired for the express purpose of making it seaworthy. Under these circumstances, since this is not traditional seaman's work, the owner should be required only to exercise due care by treating the worker as a business invitee rather than to hold out every appurtenance of the ship as fit. The work performed is more akin to land based construction activities and hence the worker in West should have no greater remedy than his land based counterpart. As a corollary, it would seem that since the harbor worker's remedy is predicated on the hazards faced by seamen, he should be included within the scope of the doctrine only when the seaman faces risks. Since it is unlikely that there will be any crew on a ship being overhauled on a dry dock, they do not require protection and hence it is unreasonable to have the warranty inure to the benefit of a worker in the West situation. It is doubtful that even the more avid supporters of Sieracki would argue with this conclusion as is exemplified by the fact that the Court in West was unanimous.

s9 E.g., Union Carbide Corp. v. Goett, 278 F.2d 319 (4th Cir. 1959), cert. denied, 364 U.S. 826 (1960); Raidy v. United States, 252 F.2d 117 (4th Cir. 1958); Berge v. National Bulk Carriers Corp., 251 F.2d 717 (2d Cir. 1958); Berryhill v. Pacific Far East Line, Inc., 
The extension of West to the Roper situation, however, does not seem to be a necessary consequence of the West rationale since the cases could easily have been distinguished if the Court had been disposed to extend the Sieracki doctrine rather than to limit its application. One ground for such a distinction is the fact concerning control of the ship. The vessel in West was under the complete control of the contractor and therefore it would have been unfair to hold the owner to the duty of the warranty. This is especially true in view of the fact that West clearly knew why he was on board the vessel. This unfairness was not present in Roper because the owner still had control of the vessel, with only the unloading process being under the control of the stevedore. As contrasted with West, Roper knew he was on board to unload the ship, not to make it seaworthy. 60 While control is a valid factor in the reactivation cases, it is not necessarily so in unloading cases because the surrender of control in the latter is not complete. Thus the Court's use of the West case manifests a reluctance to apply the Sieracki doctrine to a situation in which it might be appropriate but is not by precedent required.

Standing alone, the West decision probably did not substantially limit the Sieracki doctrine. However, the effect of Roper, decided in reliance upon West, is to diminish apprecinbly the applicability of the unseaworthiness doctrine to longshoremen and harbor workers by reducing the number of workers covered by the warranty. Heretofore the navigation prerequisite of the warranty has been employed to deny recovery under the doctrine in the West case and a small number of other situations. Roper, however, will result in the denial of recovery under Sieracki for any injuries occurring on a vessel which

238 F.2d 385 (9th Cir. 1956), cert. denied, 354 U.S. 938 (1957); Huber v. United States, 177 F. Sv:pp. 617 (N.D. Cal. 1959); Kissinger v. United States, 176 F. Supp. 828 (E.D.N.Y. 1959); Bishop v. United Ststes, 173 F. Supp. 273 (E.D.N.Y. 1958); Krolczyk v. Waterways Nav. Co., 151 F. Supp. 873 (E.D. Mich. 1957); Owens v. United States, 1958 Am. Mar. Cas. 216 (S.D. Fla. 1957). Cf. Desper v. Starved Rock Ferry Co., 342 U.S. 187 (1952). But cf. Yost v. General Elec. Co., 173 F. Supp. 630 (S.D.N.Y. 1959) where recovery was allowed because negligence was proven.

Post West decisions have followed the same pattern. See, e.g.: Noel v. Isbrandtsen Co.s 287 F.2d 783 (4Lh Cir. 1961); Moon v. United States, 1961 Am. iMar. Cas. 1305 (E.D.N.Y. 1960). The Second Circuit was willing to distinguish West where the repairs were minor, the ship was still afloat, and the crew was still aboard. I awlor v. Socony Vacuum Oil Co., 275 F.2d 599 (2d Cir. 1960). It was not, however, willing to accept the argument that as each portion of the ship was reactivated that portion was covered by the warranty. Latus v. United States, 277 F.2d 265 (2d Cir. 1960).

60 The majority in the circuit court did argue that control was an important consideration. This may be considered erroneous reasoning not only because one of the policy reasons behind Sieracki was to prevent the escaping of Mahnich liability by means of independent contracting of ship functions but also because of the decision in Alaska S.S. Co. v. Petterson, 347 U.S. 396 (1954) (per curiam), affirming 205 F.2d 478 (9th Cir. 1953). See also Rogers v. United States, 347 U.S. (1954) (per curiam); cases cited noted 12 supra. In Petterson the shipowner was held liable for injuries caused by an unfit piece of equipment owned by the stevedore. Certainly the shipowner had more control over the vessel in Roper than it had over the defective block in Petterson. 
has been deactivated. This would appear to be as true in the case of a "seaman" on such a ship as it is in the case of longshoremen, although the impact will not be as drastic. It is unlikely that there will be many seamen engaged in service on ships which, like the Harry Lane, are being used to transfer cargo, although deactivated and normally moored in a "mothball" fleet.61 Consequently, the rights of only a few seamen will be effected by the Roper decisions, 62 and probably even fewer in the case of Wesi, since it is unlikely that a ship will have a crew while drydocked for extensive repairs.63 On the other hand, the impact of Roper on longshoremen will undoubtedly be considerable. It is true that the number of such workers engaged in loading or unloading deactivated vessels will probably not be great in absolute terms. It must be remembered, however, that as many longshoremen are needed in the Roper situation as are needed in the Sieracki situation. While the effect of Roper on seamen is limited by the fact that they are seldom employed on such vessels, the effect as to longshoremen and harbor workers can only be limited to the extent that the lower courts find that deactivated vessels are still in navigation. Under the impetus of an authoritative Supreme Court decision it is likely that the latter restriction will have a considerable impact. 64

61 In Roper a licensed master and six linemen were employed to handle the ship while it was being towed from the fleet to the grainery. This is probably far less than the complement which would be necessary to navigate the Harry Lane had it been completely refurbished and recommissioned. The linemen had to be documented seamen pursuant to Maritime Commission regulations.

62 In Madsen v. United States, 186 F. Supp. 577 (E.D. Pa. 1960), a pre-Roper decision, a night relief mate was allowed recovery under the unseaworthiness doctrine for injuries sustained while the deactivated vessel was awaiting towage to a grain elevator. The court treated the navigation issue rather summarily, stating that the fact that a "dead" ship was involved made no difference. The case appears to fall squarely within Ropcr and it is unlikely that the same result would be reached to-day.

63361 U.S. at 119-20. One reason why Lawlor v. Socony-Vacuum Oil Co., 275 F.2d 599 (2d Cir. 1960) was distinguished from West was that the crew was still on board the vessel when it was undergoing its overhaul.

64 There is another effect of Roper on the rights of longshoremen, albeit indirect in nature. The determination by the Supreme Court on the navigation question made it unnecessary to decide whether the warranty extends to large, land based equipment. As a consequence another confused area of maritime personal injury law has not been clarified despite considerable need. Petterson and Rogers held that the shipowner colld be held liable for defective equipment owned and under the control of the stevedore. See note 60 supra and accompanying text. However, since both of these decisions were per curiam, there is a question as to how much of their reasoning and scope was approved. The Court has given little guidance since Petterson, the basis of Rogers, was affirmed by a citation to Sieracki where the nondelegability of the doctrine was discussed. Since the equipment involved was of a type commonly found on ships, it can be argued that the warranty does not extend to land based equipment of the type in Roper. Petterson was distinguished on this basis in McKnight v. N. M. Paterson \& Sons, 286 F.2d 250 (6th Cir. 1960), cert. denied, 368 U.S. 913 (1961); see also Fredericks v. American Export Lines, Inc., 227 F.2d 450 (2d Cir. 1955). However, it is just as reasonable to argue that the Court meant to extend the warranty to all equipment used by a stevedore, even if not commonly found on ships. This was the rationale behind DeVan v. Pennsylvania R.R. Co., 167 F. Supp. 337 (E.D. Pa. 1958), and Considine v. Black Diamond S.S. Co., 163 F. Supp. 107 (D. Mass., 1958); $c f$. Litwinowicz \& Matyas 
The result reached in Roper is consistent with the growing dissatisfaction with the application of the rnseaworthiness doctrine to longshoremen and other harbor workers. ${ }^{65}$ While the lower courts were at one time willing to apply and extend Sieracki, there has developed a reluctance to accept the full implications of its rationale. Thus in Royston v. Pacific Far East Lines, Inc.. ${ }^{66}$ the plaintiff, a National Cargo Bureau inspector injured while surveying the hold of a ship, was denied recovery on an unseaworthiness count because he was not performing "the traditional work of the crew." For the same reason, a fire watchman, injured by an explosion following the extinguishment of a fire, was denied recovery in $M c$ Daniel $v$. The $M / B$ Lisholt. ${ }^{67}$ While inspecting holds and fighting fires cannot be considered routine seamen's work, such activities are probably common enough to have been included within the scope of the "traditional work" test if the courts had been favorably disposed to the unseaworthiness doctrine. This reluctance to expand the doctrine is illustrated also by the McKnight-Considine dichotomy concerning the applicability of the warranty to land based equipment. 68 There was no logical necessity for limiting the Petterson decision, in McKnight, to equipment not commonly found on ships other than the policy ground opposing Sieracki, Pope \& Talbot, and Petterson. Similarly, the courts have been unwilling to apply the doctrine to injuries caused by top heavy cargo, ${ }^{69}$ by negligently loaded cargo, ${ }^{70}$ or by

v. Weyerhaeuser S.S. Co., 179 F. Supp. 812 (E.D. Pa. 1959); DiSalvo v. Cunard S.S. Co., 171 F. Supp. 813 (S.D.N.Y. 1959).

Notwithstanding the prevalence of the practice, the Court can be criticized for refusing to clarify this problem when the opportunity was presented. The problem of the scope of Petterson could have been disposed of in Roper even though it was held that the ship was out of navigation with the concomitant of no duty on the part of the shipowner to the plaintiff.

65 This judicial dissatisfaction is a relatively recent develcpment as compared to the longstanding displeasure with the doctrine of most writers on the subject. See generally Ambler, Seamen are "Wards of the Admiralty" but Longshoremen are Now More Privileged, 29 WASH. L. Rev. 243 (1954); Benbow, Seaworthiness and Seamen, 9 MiaMI L.Q. 418 (1955); Baer, At Sea With the Supreme Court, 38 N.C.L. Rev. 307 (1960); Gardner, Remedies For Personal Injuries to Seamen, Railroadmen and Longshoremen, 71 HARv. L. REV. 438 (1958); Tetreault, Seamen, Seaworthiness and the Rights of Harbor Workers, 39 CORNELL L.Q. 381 (1954); Comment, The Tangled Seine: A Survey of Maritime Personal Injury Kemedies, 57 YALE L.R. 243 (1947).

66190 F. Supp. 450 (N.D. Cal. 1960).

67180 F. Supp. 24 (S.D.N.Y. 1959), $a f f^{\prime} d, 282$ F.2d 816 (2d Cir. 1960). But see note 57 supra.

63 See discussion note 64 supra.

69 See, e.g., Carabellese v. Naviera Aznar, S.A., 285 F.2d 355 (2d Cir. 1960). But see Rich v. Ellerman \& Bucknell, S.S. Co., 278 F.2d 704 (2d Cir. 1960).

70 See, e.g., Arena v. Luckenbach S.S. Co., 279 F.2d 186 (1st Cir. 1960). See also Phipps v. N.V. Nederlandshe Amerikaansche Stoomvart, Maats, 259 F.2d 143 (9th Cir. 1958) (doctrine not applicable to situation where injury occurred while vessel was being loaded in the ordinary manner). Knox v. United States Lines Co., 186 F. Supp. 668 (E.D. Pa. 1960) (negligent handling of properly stowed cargo did not constitute an unseaworthy condition). 
negligent use of seaworthy equipment. ${ }^{71}$ If the unseaworthiness doctrine was made absolute because of the "hazards" endemic"to maritime activities, recovery in these cases could be said to be within that purpose. Certaintly it would have been no less reasonable to allow recovery under the above circumstances than it was to extend the warranty to a longshoreman injured while on the dock because he was engaged in the "service of the ship,"72 or to a longshoreman injured as a result of his negligent handling of a hatch cover because it had become a part of the "working surface of the vessel."73 Perhaps this lower court trend can be best described as a shift from a willingness to allow recovery under the unseaworthiness doctrine even where the vessel was patently out of navigation, 74 to a begrudging application of Supreme Court precedents.75 Furthermore, the Suprme Court itself has limited the application of the unseaworthiness doctrine by several other decisions in the past few years.

In United N.Y. \& N.J. Sandy Hook Pilots Ass'n v. Halecki,76 a wrongful death action, the plaintiff's cause of action was rejected under the doctrine because the use of specialized equipment by her decedent in the cleaning of the ship's appurtenants did not constitute traditional crew's work. Halecki had died as a result of carbon tetrachloride poisoning ensuing from the use of the chemical in the cleaning of the ship's generators in an area with inadequate ventilation. The Court reasoned that while cleaning the ship might be a traditional duty of the crew, 77 no seamen had ever used the particular method

71 See, e.g., Morrell \& Valle v. United States, 193 F. Supp. 705 (N.D. Cal. 1960); Green v. Skibs A /S Mandeville, 186 F. Supp. 459 (E.D.S.C. 1960), But cf. Manhat v. United States, 220 F.2d 143 (2d Cir.), cert. denied, 349 U.S. 966 (1955).

72 See, e.g., Pope \& Talbot, Inc. v. Cordray, 258 F. 2d 214 (9th Cir. 1958).

73 See, e.g., Grillea v. United States, 232 F.2d 919 (2d Cir. 1956). See also Reddick v. McAllister Lighterage Line, Inc., 258 F.2d 297 (2d Cir.), cert. denied, 358 U.S. 908 (1958).

74 See Pioneer S.S. Co. v. Hill. 227 F.2d 262, 263 (6th Cir. 1955) (dictum).

75 Holley v. S.S. Manfred Stansfield, 186 F. Supp. 212, 215 (E.D. Va. 1960). For other decisions showing the earlier attitude see, e.g., Mesle v. Kea S.S. Corp., 260 F.2d 747 (3d Cir. 1958); Torres v. The Kastor, 227 F.2d 664 (2d Cir. 1955). Cf. Pleason \& Dorfman v. Gulfport Shipbuilding Corp., 221 F.2d 621 (5th Cir. 1955); Strika v. Netherlands Ministry of Traffic, 185 F.2d 555 (2d Cir. 1950), cert. denied, 341 U.S. 904 (1951). But see Fredericks v. American Export Lines, Inc., 227 F.2d 450 (2d Cir. 1955).

For other examples of the later attitude, see, e.g., Billeci v. United States, 298 F.2d 703 (9th Cir. 1962); Partenweederei v. Weigel, 299 F.2d 897 (9th Cir. 1962). Pichirilo v. Guzman, 290 F.2d 812 (1st Cir. 1961); Kent v. Shell Oil Co., 286 F.2d 746 (5th Cir. 1961). Cf. Cimino v. United States, 1960 Am. Mar. Cas. 2120 (S.D.N.Y. 1960); Ezekiel v. Volusia S.S. Co., 297 F.2d 215 (2d Cir. 1961). But see Litwinowicz \& Matyas v. Weyerhaeuser S.S. Co., 179 F. Supp. 812 (E.D. Pa. 1959); Casbon v. Stockard S.S. Corp., 173 F. Supp. 845 (E.D. Pa. 1959); DiSalvo v. Cunard S.S. Co., 171 F. Supp. 813 (S.D.N.Y. 1959). For a particularly emphatic attack on this trend, see the dissenting opinion of Judge Clark in Puddu v. Royal Netherlands S.S. Co., 1962 Am. Mar. Cas. 419 (2d Cir. 1962), where a petition for rehearing was denied by the Second Circuit sitting en banc. See also cases cited note 59 supra.

76358 U.S. 613 (1959). See generally Note, 37 N.C.L. Rev. 479 (1959).

77 There would seem to be no reasonable grounds to question the historical accuracy of this premise, while the opposite is true in the alleged traditional work test of Sieracki. See note 22 supra. 
employed in Halecki. Because of the unusual nature of the equipment and the necessary expertise required for its operation, the Court held that the SierackiPope \& Talbot line of cases could not apply. Like Roper, the Halecki case manifests a dissatisfaction with the Sieracki doctrine. This was clearly pointed out by Mr. Justice Brennan's dissent, which contended that the Court had rejected

[c]lear categorical analysis between Halecki's work and that historically done by crew members, with the observations that the work Halecki was doing was different because the vessel was modern, had complicated equipment, and required specialized treatment efficiently to perform the work on it. Thus the whole point of the Sieracki decision is turned around, and today's shipowner escapes his absolute duty because his vessel is modern and outfitted with complicated and dangerous equipment and because a pattern of contracting out a sort of work on it has become established. 78

It should be noted, however, that Halecki may not have limited Sieracki so clearly as West and Roper, since it has thrust upon the lower courts the problem of determining not.only what is traditional crew work but also what is the traditional way such work is effected. ${ }^{79}$ Halecki was remanded for a determination of the negligence count under the state wrongful death act.80 In this respect it is similar to The Tungus v. Skovgaard.81 However, in Skovgaard an unseaworthiness claim was allowed, albeit contingent on the existence of such a claim in the state act. In one respect, this decision was an extension of the harbor worker's rights under the doctrine because it permitted a cause of action for a wrongful death under maritime conditions which is not allowed in general maritime law. The Supreme Court bound itself by the circuit court's determination that the state law had encompassed the federal maritime doctrine of unseaworthiness. But in achieving the Skovgaard result, the Court rejected the Pope \& Talbot dictum which stated that "even if Hawn were seeking to enforce a state enacted remedy for this right [unseaworthiness], federal maritime law would be controlling." 82 This position, taken by the Chief Justice and Justices Brennan, Black and Douglas, is logically questionable. There is nothing inherent in Sieracki that requires the application of the unseaworthiness doctrine under circumstances in which the injured party might not have had a remedy at all. But, even if this view is rejected, it is clear that the Skovgaard decision has made the unseaworthiness remedy uncertain in

78358 U.S. at 623 (dissenting opinion).

79 This problem was prognosticated in the dissent. Id. at 624 .

80 There is no federal wrongful death act for deaths not occurring on the high seas, i.e., one marine league from shore. Death on the High Seas Act, 41 Stat. 537-38 (1920), 46 U.S.C. $\$ \$ 761-68$ (1958). For deaths without this act's coverage, the law of the contiguous state applies.

81358 U.S. 588 (1959). See generally Note, 37 N.C.L. REv. 479 (1959).

82346 U.S. at 409 . See generally id. at 409-11. 
wrongful death situations because the lower courts must decide not only whether the doctrine has been encompassed by the various state acts but also whether it has been adopted subject to any of the common law tort defenses which might exist within the particular jurisdiction if the first determination is in the affirmative. 83

While the trend has been away from the extension of the doctrine for longshoremen, the courts have been willing to extend it for seamen. In Boudoin $v$. Lykes Bros. S.S. Co.,84 a seaman was held to be within the scope of the doctrine for injuries suffered from an attack by a shipmate whose dangerous propensities were held to render the ship unseaworthy. This was a reasonable extension because an unfit crew can be as dangerous as an unfit ship. However, the doctrine does not apply where the seaman is of ordinary temperament. 85 Neither does it apply to guests of seamen injured because of an unseaworthy condition. 86 Another example of this willingness to increase the seaman's rights was Mitchell v. Trawler Racer, Inc.87 In Mitchell the Court

83 It should be pointed out that in one area the rights of harbor workers have been expanded because of the dissatisfaction with the unseaworthiness doctrine in particular rather than with the scope of such workers' remedies in general. This expansion is exemplified by Senko v. LaCrosse Dredging Corp., 352 U.S. 370 (1957). See also Butler v. Whiteman, 356 U.S. 271 (1958); Grimes v. Raymond Concrete Pile Co., 356 U.S. 252 (1958); Gianfala v. Texas Co., 350 U.S. 879 (1955). In Senko a common laborer, who perchance was employed on a dredge, was allowed to bring a negligence action as a seaman under the Jones Act. This extension of the Jones Act remedy to workers clearly not members of a crew, as that phrase is normally understood, has been said to be an implicit overruling of Desper v. Starved Rock Ferry Co., 342 U.S. 187 (1951), which held that a seaman by vocation did not come within the purview of the act while working on pleasure boats off season. See generally Baer, supra note 65 , at 371-78. While the Court may very well be criticized for this unwarranted distortion of congressional intent in enacting the Jones Act, it does not really effect the recent trend in regard to the unseaworthiness doctrine under Sieracki.

Another problem in the unseaworthiness area is that of the right over of a shipowner against a stevedore who had created the unseaworthy condition and the concomitant problems of $\$ 905$ of the Longshoremen's Act. See Crumady v. Joachim Hendrik Fisser, 358 U.S. 423 (1959); Ryan Stevedoring Co. v. Pan-Atlantic S.S. Co., 350 U.S. 124 (1956). While the treatment of this problem by the courts can effect the longshoreman's and harbor worker's right under the doctrine, it is at best peripheral because under Czaplichi v. S.S. Hoegh Silvercloud, 351 U.S. 525 (1956), it was held that the longshoreman could still press his claim against the shipowner despite having received compensation under the Longshoremen's Act. Normally, the longshoreman's claim would be assigned to his employer, and then probably subrogated to his insurer. Since the stevedore would be liable if the condition was created by him, it is unlikely that he would press the longshoreman's assigned claim against the shipowner.

For more thorough coverage of the right over question, see Baer, supra note 65, at 36771; Weinstock, The Employers' Duty to Indemnify Shipowners for Damages Received by Harbor Workers, 103 U. PA. L. REv. 327 (1954); White, A New Look at the Shipowner's RightOver for Shipboard Injuries, 12 STAN. L. REV. 717 (1960); Note, 34 NoTRE DAME LaW. 576 (1959).

84348 U.S. 336 (1955).

85 Jones v. Lykes Bros. S.S. Co. 204 F.2d 815 (2d Cir.), cert. denied, 346 U.S. 857 (1953).

86 Kermarec v. Compaigne Generale Transatlantique, 354 U.S. 625, 629 (1959).

87362 U.S. 539 (1960). 
held that a "transitory" unseaworthy condition, i.e., a defect which arises during the course of a voyage which is temporary rather than permanent in nature, comes within the scope of the doctrine, even though the owner had no notice of its existence. Under the prior law, notice was a condition precedent to liability under such circumstances. 88 The seaman has benefitted from Mitchell because there are many minor defects which can arise during a voyage and result in making the vessel unfit. The abrogation of the notice requirement in transitory cases was the logical culmination of the theory that the doctrine of unseaworthiness is absolute in nature. 89

It is therefore submitted that while the law of maritime personal injuries was by no means completely clarified by Roper, the decision fits into a discernible pattern of recent Supreme Court and lower court law. Sieracki started an expansion in favor of longshoremen and harbor workers, while West and Roper seem to portend a waning of the doctrine. Since, however, there are many close decisions in this area there is still considerable instability within this trend. It would seem that at the present time the Sieracki doctrine would not apply to situations where the worker is employed on ships which can in any way be said to have been withdrawn from active use. The Roper decision appears to have abrogated the need that this withdrawal be patent. A second requirement for the application of the doctrine as it now stands is that the injured party must not have used specialized or extraordinary equipment or procedures. As a consequence of the recent pattern of decisions, there exists an inequality in the remedies available to the members of the same class of harbor workers but who are employed in different situations. For example, while the longshoreman in Roper is deprived of the unseaworthiness remedy, the

88 See, e.g., Cookingham v. United States, 184 F.2d 213 (3rd Cir. 1950). But see Poignant v. United States, 225 F.2d 595 (2d Cir. 1955).

89 While Mitchell has benefited the seaman, see, e.g., Puerto Seguro Cia Nav. v. Pitsillos, 279 F.2d 599 (4th Cir. 1960); But see Blier v. United States Lines Co., 286 F.2d 920 (2d Cir. 1961), Colon v. Trinidad Corp., 188 F. Supp. 97 (S.D.N.Y. 1960). It has also benefited the longshoreman, e.g., Grzybowski v. Arrow Barge Co., 283 F.2d 481 (4th Cir. 1960). Calderola v. Cunard S.S. Co., 279 F.2d 475 (2d Cir. 1960); Merrill v. S.S. Cuaco, 189 F. Supp. 321 (D. Ore. 1960). But see Carabellesz v. Naviera Aznar S.A., 285 F.2d 3..5 (2d Cir. 1961); Cooper v. A/S Progress, 188 F. Supp. 589 (E.D. Pa. 1960).

In Morales v. City of Galveston, 291 F.2d 97 (5th Cir.), cert. granted, 368 U.S. 816 (1961), the Court is presented with the problem of the transitory unseaworthiness condition in the context of the longshoreman's rights. The Circuit Court held that contaminated grain in an otherwise staunch and fit vessel did not constitute an unseaworthy condition. The case appears to fall squarely within Mitchell, even though the court attempted to distinguish it. The reliance on the fact that the vessel was otherwise staunch is not impressive because the railing in Mitchell was not defective except for the fish "gurry." See generally Note, 47 VA. L. REv. 1428 (1961). While the rights of seamen are limited to some extent by Roper, see notes 61-62 supra and accompanying text, and the rights of longshoremen have been increased by Mitchell, the net effect will probably benefit the iormer because of the greater likelihood of a transitory unseaworthy condition developing during a voyage than during unloading operations. It is doubtful, however, that Boudoin will benefit longshoremen because the opportunities for the display of dangerous propensities are much fewer during unloading operations than during a voyage. 
longshoreman in Sieracki is still protected. Since the longshoreman possesses adequate remedies under the Longshsremen's Act and common law negligence suits, it is arguable that Sieracki should be overruled. That decision is probably too far entrenched, however, to be set aside without congressional action. Furthermore, the seaman who actually encounters the hardships of maritime activities ${ }^{90}$ has lost some of the protection of an absolute tort doctrine as an incidence of the limitation placed upon the remedies available to land based workers. Finally, there are a number of other factors which favor an overruling of Sieracki. If the harbor worker was effectively limited to the relief of the compensation act, there would be a decrease in litigation over the apptication of the doctrine, since it would apply only where the injured worker could be considered a seaman rather than to the larger class of longshoremen and harbor workers.

An additional benefit which would stem from the overruling of Sieracki would be a lessening of the problems confronting a purchaser of marine insurance. The possibility of liability to any one of a great number of workers, in conjunction with the already high cost of maritime insurance, could very easily raise the cost to a point where owners of foreign ships would eschew sending their vessels into this country's ports in order to effect economic savings. ${ }^{91}$

Because of the unknown effect of the recent shift in personnel on the usually close decisions and the constant possibility of congressional action, it is difficult to predict if the Court will stay within the recent trend of decisions. The next areas the Court will probably have to consider are those involving the unanswered second question of the Roper case and the scope of Halecki in regard to equipment not commonly found on board ships. If there is not a reversal of the present trend, it is likely that the Court will hold that the warranty of seaworthiness does not apply to large land based equipment even though it might be commonly used in the loading and unloading ships, or to the equipment usually employed only in land based activities but which happens to have been on board a ship at the time of the injury. In regard to the areas which have already been dealt with in Supreme Court decisions, there will probably be a continued reduction of the scope of the traditional seaman's work and an increase in types of factual situations which constitute the withdrawal of a ship from navigation. The consequence of such judicial determinations might be to achieve by indirection a rejection of Sieracki no less effective than would be a decision actually to overrule it.

90 This is not, however, an universally accepted premise. See generally Lovitt, Things are Seldom What They Seem; the Jolly Little Words of the Admiralty, 46 A.B.A.J. 171 (1960); Wood, "Old Father Antic the Law": The Favorites of the Courts of Admiralty, 41 A.B.A.J. 924 (1955). But see Norris, The Seaman as Ward of the Admiralty, 52 MICH. L. REv. 479 (1954); Standard, Are The Admiralty's "Jolly Little Wards" Really so Privileged?, 46 A.B.A.J. 1323 (1960).

91 See N.Y. Herald Tribune, March 31, 1962, p. 20, col. 2. 